\title{
THE PROBLEMATIC STATUS OF GENDER-NEUTRAL LANGUAGE IN THE HISTORY OF PHILOSOPHY: THE CASE OF KANT
}

\section{PAULINE KLEINGELD}

In the writings of many past philosophers, the use of general terms such as "humanity", "human beings", and (understood in the generic sense) "man" belies the exclusion of women. Some philosophers made this exclusion explicit, arguing that women are "naturally" inferior to men, that they should be excluded from the public, political and economic spheres, and that they should obey their male superiors. Others have regarded it as unnecessary to justify these views in terms of their own philosophical theory, assuming the inferiority and subjugation of women to be "natural" or obvious. ${ }^{1}$

The question for philosophical commentators, historians of philosophy, and theorists today is how to approach such cases. Should one, in discussing the work of such philosophers, go on using terms such as "humanity" and "human being" when it is clear that the philosopher in question did not mean to include women? Is it legitimate to introduce explicitly inclusive language ("she or he") in presenting this philosopher's views? Or should one replace terms like "the human race" with "males"'?2

In this article, I wish to explore this issue by looking at the case of Immanuel Kant, concentrating on the work of his "critical" period. Kant is an interesting case in point, since his writings are marked by an important tension between his generic language and theory, on the one hand, and his views on the status of women, on the other. Although a forceful advocate of the Enlightenment, with strong views about the autonomy and equality of "all human beings," Kant makes crucial exceptions for women, excluding them from the public, political and economic spheres, and even denying them the capacity for personal autonomy.

After briefly presenting Kant's views on the relation between the sexes, I address the question how one should deal with the fact that he apparently only means "men" (masculine) when he speaks of "human beings" in his moral and 
political philosophy. I will discuss several different answers to this question, focusing on the approach taken in the majority of recent work on Kant's moral and political philosophy, namely, the insufficiently critical appropriation of Kant's generic language. I will argue that the arguments in favor of this approach are inconclusive, and that instead of ignoring Kant's sexism and the tensions it produces within his thinking, one should make them explicit and analyze the way in which his views on the different characters of the sexes affect his moral and political philosophy.

\section{KANT'S VIEWS ON THE SEXES}

In his works on moral and political philosophy, Kant generally uses the words "Mensch" 3 and "Menschheit" in discussing principles of ethics and politics. These principles are explicitly meant to be valid for all human beings - even, as with the categorical imperative, for "all finite rational beings." Kant asserts both the equality and the autonomy of all human beings, as beings who are all equally endowed with intrinsic worth.

Upon closer examination, however, the generic, gender-neutral language proves to be misleading. For Kant regards men as naturally superior to women, and women as unfit for the public, political and economic domain. He thinks of the concept of a female scholar as bordering on a contradiction in terms, and even attempts to ground the idea that women have a separate "vocation" and "virtue" in the assertion that they can only act upon their inclinations. ${ }^{4}$

Kant's fullest account of his views on the sexes we find in the Anthropology from a Pragmatic Point of View, in which he dedicates a section to the "Character of the Sexes" (VII,303-311). Here, he mentions three female character traits that are central to his ideas about the female character, and how it differs from the male character. ${ }^{5}$ From the outset he makes clear that he regards these differences between men's and women's character as due to a divine "higher order," and thus as necessary, unchangeable and purposeful (Anthr., VII,305f.). First, Kant thinks women are naturally weak and fearful, whereas men are strong and courageous (Anthr., VII,306). Kant presents women's fear as the direct consequence of the biological fact that they bear children. This link with biology makes it impossible to view this character trait as contingent and merely culturally determined. The salient point about this difference between men and women is not so much that women, according to Kant, need male protection. More important is the fact that he calls courage a part of virtue (Rel, VI,183, cf.VI,57) or even a virtue itself (Anthr., VII,256). In this light his statement that women lack courage gains its significance. In his famous essay "An Answer to the Question: What is Enlightenment?" Kant calls courage a necessary requirement for taking the step to "Mündigkeit," i.e. for a human being's (Mensch) release 
from self-incurred tutelage (VIII,35). Women are supposed to lack courage. Thus, again, what is claimed to be a distinctive characteristic of women, fearfulness, runs counter to a precondition for a "human" ideal, namely, that of Mündigkeit. ${ }^{6}$

A second characteristic is women's ability to manipulate men. Kant mentions the "purposeful"' side of this, namely, the fact that women contribute to men's preparation for morality, because they force them to behave courteously (VII,306). Note, the claim is not that women make this contribution by virtue of their own moral standing. Quite the contrary. Although Kant grants them eloquence and modesty, these qualities do not imply a moral disposition at all. Instead, Kant says that women force men to cultivate themselves because they are "precociously shrewd in claiming gentle and courteous treatment by the male, so that he finds himself fettered by a child through his own generosity and led by it, if not to morality itself, at least to its clothing, the cultivated propriety that is the preparatory training for morality and its recommendation" (VII,306, emphasis added). This description of women as children is meant to emphasize women's immaturity and should not be taken literally. Kant does not think women are children.

This brings us to a third characteristic, namely women's incapacity for autonomy. Unlike the first two characteristics, the third is not mentioned directly by Kant, but it is implicit in many of his remarks, and can easily be brought out. He writes: "[T] he woman should reign and the man govern; for inclination reigns and understanding governs"' (VII,309). A husband, says Kant, is to his wife as a sensible minister "to his monarch who only thinks of amusement" (VII,310). These and similar passages show that Kant assumes that women act only on "inclination," whereas men have the capacity and the obligation to use their reason. He calls it a "feminine principle" to hold that "[w]hat the world says is true, and what it does, good" (VII,308), a "principle" that is obviously hard to unite with the "Mündigkeit" Kant calls for in the Enlightenment essay.

In accordance with women's purported different capabilities, Kant distinguishes between "feminine" and "masculine virtue", (VII,307; cf. also VII,257), asserting that both have a different "incentive,"' and that women have "their own vocation" (ibid.). The significance of these statements from the Anthropology becomes clear against the background of the Foundations of the Metaphysics of Morals and the Critique of Practical Reason. There, Kant maintains (1) that the only principle of morality is the autonomy expressed in the one fundamental law of pure practical reason (from which the only concept of virtue is derived) (Pr.R.,V,31), (2) that the only true incentive to morality is respect for the moral law (Pr.R.,V,78), and (3) that "the" vocation of humanity is to act morally and strive for the highest good (Pr.R.,V,146). By ascribing to women a separate virtue, incentive, and vocation, Kant implies that the central tenets of 
the critical practical philosophy are not applicable to women, and thereby commits himself to a double standard. ${ }^{8}$

Because women, according to Kant, are weak, fearful, and guided by their inclinations - that is, because women cannot act autonomously or think for themselves - they need the competent guidance of men. For most women, Kant generally assumes, these guardians are their husbands.

There are some elements of reciprocity in Kant's account of marriage law in the Metaphysics of Morals, for example the fact that husband and wife own each other, and that they enjoy an equality of possession with regard to each other's goods and sexual organs (M.M.,VI,278). ${ }^{9}$ With this, Kant declares his opposition to a one-sided exploitation of women by men. It would be a mistake, however, to conclude from this that Kant views marriage as an enclave of egalitarianism in a partriarchal society. ${ }^{10}$ As Susan Mendus correctly remarks, this reciprocity does not imply equality. ${ }^{11}$ Kant holds that a husband has the right to give orders and that his wife should obey. He is his wife's "master" (Herr) because of his "natural superiority" (M.M.,VI,279). He has final decisionmaking power in important matters. ${ }^{12}$

Thus, although Kant sometimes ascribes women "domination" in the domestic sphere (she "reigns"), this dominant status is confined within limits that are set by the husband. Moreover, it is a kind of domination that does not mean much to him. Even where she "reigns" according to her inclinations, he still "governs" and "relies on the right of the stronger to command in the house" (Anthr.,VII,304). ${ }^{13}$ And when he gives in to her whims, that is only because he has more important things to do: thus, a man "readily submits himself to her [his wife's] regime" and motivates this by adding "so that he will not be prevented from attending to his own business"' (Anthr.,cf.VII,210).

Women have to be legally represented by men. "A woman, regardless of her age, is [declared to be] under civil tutelage; her husband is her natural curator, though if a married woman has property of her own, it is another man" (ibid., VII,209). Tellingly, Kant treats the necessity of representing women in civil affairs in a section of the Anthropology entitled "On Mental Deficiencies in the Cognitive Power" (VII,204ff.). Women are under permanent male guardianship. They have no legal competence, cannot go to court (ibid.), have no access to the economic "market;" their domestic work is not recognized as labor, and they are dependent on their husbands for support. Furthermore, they lack the right to citizenship (M.M.,VI,314; $T \& P, \mathrm{VIII}, 295)$. They are "passive citizens" - the term "citizen" here being little more than a euphemism.

This exclusion cuts across everything Kant holds valid and important for "humans" (Menschen). Men (males) who are not "their own master" lack active citizenship, too. But Kant himself feels that this is a problematic point, and argues that the status of a passive citizen may never be definitive. However, 
in the same section where he argues that it must always be possible for "everyone" ("alle im Volk") to improve their status and to work up from "passive" to "active" citizenship (VI,314f.), Kant rules out, without comment, the possibility of women ever achieving active citizenship. Similarly, in the essay "On the Common Saying: 'This May be True in Theory, but it Does not Apply in Practice,' "' Kant states that the only requirement for being a citizen is "being one's own master," only to add, as if it were a trivial afterthought: " apart from the natural [requirement] (that one [es] is not a child, not a woman)", (VIII, 295). ${ }^{14}$

It is worth listing what women lack by not having proper citizenship. They lack all three juridical attributes of a citizen, listed at the beginning of $\$ 46$ of the Metaphysics of Morals. They lack (1) the "lawful freedom to obey no law other than one to which he [the citizen] has given his consent," (2) the "civil equality of having among the people no superior over him except another person whom he has just as much of a moral capacity to bind juridically as the other has to bind him;"' and (3) the "civil independence"' that he does not owe his existence and support to the arbitrary will of another person in the society (cf.VI,314). Thus, women are dependent on an adult male's will for their existence and support, they have a male superior as their guardian and master, and, finally, they have to obey laws to which they have not been allowed to give or deny their consent. Again, we can conclude that Kant uses a double standard, one applying to "everyone" but actually excluding women, and another applying to women.

The presence of an implicit double standard in Kant's thought is also evident from what he does not say. Although Kant usually is pre-eminently able to distinguish between what is and what ought to be, he criticizes neither women's purported mode of thought, nor their social status. If he applied the same standard to women as he applies to men, he would have had to advocate women's liberation from tutelage, advocate granting them civil rights, and advocate better education for girls. But he does nothing of the kind. Instead, as mentioned earlier, Kant speaks of a "natural superiority" of men, and regards the character and role of women as part of a higher purposive order, namely, as an "end of Nature"' (Anthr., VII,305f.).

To summarize, there is a strong tension between Kant's generic theory (that applying to human beings, to "everyone") and his gender-specific views (where women represent the deviant case). Kant does not justify the inferior status of women in terms of what he holds valid for "human beings," and such a justification would indeed be impossible.

Apart from this general tension, more specific difficulties emerge from Kant's views on the different characters of the sexes, such as the obscure link between biology (sex) and rational capacities, or the fact that Kant makes vast generalizations about "the" character of women (and men) on the basis of very limited, 
and class-bound, experience. This list could be extended, but I will not elaborate on these difficulties here. Nor will I discuss the issue of the implications of a re-evaluation of Kant's views on the sexes for his moral theory, although I will come back to this issue at the end of this essay. I wish instead to concentrate on the question how to deal with Kant's views on the different characters of the sexes and with the tension between his generic and gender-specific claims as they stand. I shall first discuss three different answers to this question.

\section{THREE APPROACHES TO KANT'S VIEWS ON THE SEXES}

The first way of dealing with Kant's views on the different characters of the sexes is simply to accept them and leave unacknowledged the tension between these and Kant's otherwise generic language. This position has often been taken. From the eighteenth century up to now, a number of scholars have explicitly admired Kant's characterization of the sexes. For example, at an 1877 meeting of Königsberg's Kant-Society, Benno Bobrik presented Kant's ideas in order to deploy them against emancipatory tendencies of the day. According to Bobrik, Kant's ideas promised to be of "general[!] interest," "especially in our day, now that people are attempting to break through the natural boundaries of women's knowledge and understanding." ${ }^{15}$ About fifty years later, Karl Vorländer calls Kant's description of women's character an "attractive characterization of the female sex." 16 And recently, Roger Scruton has praised Kant for writing "eloquently on the distinction between the sexes." these philosophers follow Kant in their tendency to use generic language but exclude women, to speak about women only where Kant does so, and to pass over any inconsistencies in this regard. Since, however, they fail to see the tensions involved here, this approach is not adequate.

A second way of handling Kant's views on the sexes could be to reject Kant's moral and political philosophy out of hand as thoroughly misogynous. If reason does not prescind from gender, if Kant only thinks of reason in the full sense as reason of men, then clearly his whole practical philosophy is irrevocably misguided.

To defend this position one would have to argue for two separate claims. First, one would have to show that there is no place where Kant transcends his "male" point of view, i.e. that in every passage in which he writes about the human race he is actually writing just about men, and that wherever he writes "Mensch" he 
actually only means "Mann." Second, one would also have to show that there is no way in which feminists can make use of his thought. The first claim is not all that implausible, given the exceptional status that Kant accords to women. The second claim, however, may be more difficult to make good on. For, even if Kant's account of "masculine virtue" perfectly maps that of virtue simpliciter (applying to human beings and other "finite rational beings"), the case must still be made that his concept of virtue is thereby completely worthless. One would have to prove that everything that Kant calls "human" neither could nor should count as truly human, i.e. that there are no elements in his ideal of humanity/ masculinity which he wrongly limits to the male sex.

Furthermore, it is worth noting that feminism is, to a significant degree, anchored in the Kantian Enlightenment tradition and has often claimed that Kant indeed wrongly limits concepts as respect for the individual, dignity, freedom, equality, independence, autonomy to the male sex. And although many feminist thinkers may wish to modify some of these concepts-for example, by replacing Kant's stress on independence in favor of a model that stresses interdependence- they may wish to retain others.

Thus, those who would wish to take the strong position that Kant's philosophy is thoroughly corrupt would have to argue for it, since it is not self-evident. A rejection out of hand is not possible.

\section{III}

The third way of dealing with Kant's views on the sexes and with the tension between his generic and his gender-specific theory is the one almost universally chosen in mainstream contemporary Kant scholarship. This third option is to say that Kant's views on women are mistaken, that one should instead concentrate on his more important philosophical achievements, and that one can simply leave his theory about the sexes aside. Roger Sullivan has recently stated: "In general, Kant's views about women and marriage . . . are still best ignored and forgotten." 18

Among philosophers who hold this view, two different attitudes can be distinguished with regard to how they write about Kant's "more important" philosophical work: Some use explicitly inclusive language, others do not. ${ }^{19} \mathrm{I}$ shall first say something about the use of the "we"-form, the use of generic terms, and the use of inclusive language, and then address the issue of whether one can ignore Kant's views on the sexes or not.

Most authors who write about Kant's moral and political philosophy, even many of those who are critical of the dependent status that Kant assigns to women, nevertheless take over Kant's generic language. Throughout their discussions, they speak of "men" (meant generically) or "mankind," 20 even 
though often this cannot be understood as applying to women. Most also use the "we"-form, as, for example, in explaining Kant: "We are as citizens to act 'as if' such a contract existed." ${ }^{21}$ However, as shown above, Kant does not extend citizenship to women. Thus, unless the author is assuming an entirely male and "independent" readership, the use of "we" here is misleading. ${ }^{22}$

This problem is even more acute when authors use explicitly inclusive language. However appropriate inclusive language generally is, in some cases it can lead to significant distortions. It is, for example, a distortion of Kant's views to speak of "the moral demands of both the Enlightenment and the moral law that each person renounce all 'tutelage' and think for himself or herself.,"23 The problem here is twofold. First, the inclusive language in the passage just quoted is a distortion of what Kant meant. Kant did not say women should renounce all tutelage and think for themselves; in all important matters they should leave it to their husbands to decide and think for them. Second, using inclusive language in rendering Kant's thought makes his sexism more difficult to identify. By suggesting that he was more of an egalitarian than he really was, it occludes systematic tensions in Kant's thought and reduces the motivation for an investigation into Kant's actual views on the sexes.

Many authors who know Kant's views on the sexes nevertheless use generic or inclusive language in presenting and discussing his moral and political theory. They probably do so on the assumption that one can easily ignore Kant's gender theory. This assumption often remains implicit and unaccounted for, but sometimes authors give reasons for it. I will here discuss three claims which can be found in recent Kant-literature.

1. The first claim can be formulated as follows: Kant does not discuss the characters of the sexes in his Critiques, therefore this issue clearly does not affect transcendental philosophy and is not important. ${ }^{24}$

Against this several points can be made. First, the fact as such that Kant does not discuss the issue in his Critiques does not show that it isn't important; the most it can show is that Kant does not treat it as important, leaving unanswered the question whether Kant is wrong or not in doing so. Thus, in this case, one could just as well argue that Kant did not treat the issue in his Critiques because he did not consider the subjugation and supposed inferiority of women to be a serious matter.

The second point is more complicated. It is true that Kant apparently does not want to give transcendental status to the sexual difference. Women as well as men are rational beings, he says in the Anthropology (VII,303). Nowhere in his critical work does Kant draw a distinction between two different kinds of reason (which he could hardly be expected to do). From this, one might conclude that as far as Kant's analysis of reason as such is concerned, this analysis equally holds for reason in men and reason in women. But there is more to be said. For 
if women do have the same rational capacities as men, their legal and mental tutelage stays unaccounted for. And, indeed, Kant seems to have in mind a sort of explanation of women's condition. From another passage in the Anthropology we can infer that he thinks the problem with women's reason is not so much that it is different in nature, but that "its exercise involves deficiencies" (VII,208, asserting the necessity of civil tutelage of women). If this is what Kant has in mind, i.e. if he supposes that the exercise of women's reason "involves deficiencies" and that this explains their condition, then indeed everything he says about the dignity and vocation of humanity, for example in the Critique of Practical Reason, applies de facto only to men (males). For these "deficiencies" cause women to fall far short of the moral ideal that men ought to strive for. Then, the sex/gender difference does exist on the level of a Critique, albeit not visibly through stipulating a different reason for women, but invisibly through the back door of saying that their reason is deficient. And this is important on the level of transcendental practical philosophy itself, in that it effectively excludes half of humanity from everything that constitutes the "worth" and "vocation" of human beings.

Finally, the fact that Kant does not explicitly exclude women in the Critiques does not imply that he included them. To assume that women are included since Kant uses the word "Mensch" is to beg the question. When Kant wrote, the onus probandi in matters concerning the relationship between the sexes still rested with the advocates of emancipation and equality. Therefore it may in this case be more accurate to assume that women are excluded unless stated otherwise. ${ }^{25}$

2. The second claim to the effect that Kant's views on the sexes can be ignored runs as follows. Kant's pre-philosophical assumptions should be distinguished from his main philosophical concern. Thus, for example, in the Metaphysics of Morals, Kant's assumption of the "natural superiority" of men (VI,279) belongs to the category of pre-philosophical assumptions, whereas his real achievement lies in the central principles of his political philosophy. The former are inessential details that can be left aside, while the latter meets the standard of a priori justification that Kant himself regarded as most important. ${ }^{26}$

Now of course it is possible to make a distinction between essential and inessential elements in Kant's writings, and indeed one can sometimes leave out an inessential element without affecting the rest at all. Thus, for example, Kant could presumably have changed his views concerning the nutritiousness of the first mother's milk $(E d$.,IX,456) without affecting the principles of his theory of education. But not all "pre-philosophical assumptions" are inessential in this sense. Moreover, the distinction between essential and inessential elements is usually more difficult to draw then in the example just given.

If one wants to justify ignoring what Kant wrote about the sexes with the claim 
that it is inessential, it should be shown that these views are inessential, easily removable details - but this would be difficult. For, to stay with the example of the Metaphysics of Morals, Kant's views on the sexes imply particular political institutions, a split between the public, political and economic male-dominated sphere on the one hand, and the domestic, reproductive female sphere on the other, a division of labor according to sex, an undervaluation of reproductive and domestic labor. All of these elements of Kant's political philosophy are intimately connected with his views on the sexes, thus making it impossible to regard the latter as inessential and negligible.

3. The third claim used to justify ignoring Kant's views on the sexes is that we have to see that Kant is a child of his time, that we "must not forget to study his opinions in the light of that day," 27 that he is subject to "historical limitations," ${ }^{28}$ and that "he is not unique in the fact that he reflected some of the prejudices of his time." 29 Sometimes references to Kant's biography are added, to the effect that Kant, as a bachelor who lost his mother early on and avoided all contact with his sisters, was "not the man to do justice to women." 30

With regard to this third claim, two points deserve discussion, one concerning the contents of the claim itself (a), the other concerning its presuppositions (b).

a. It is true that views of male superiority and female inferiority were more widely held in Kant's time than they are now. Studying Kant's views "in the light of that day" may make us more lenient in judging him as a person, however critical one may still be of his views. But there are limits to this clemency. In Königsberg, at the end of the eighteenth century, the "historical limitations", were not insurmountable. I will mention some examples, which show that Kant held on to his views against different kinds of resistance.

To begin with, Kant was familiar with the existence of learned women, such as the well-known Mme. du Chatelet and Mme. Dacier, whom he mentions in his early essay "Observations on the Feeling of the Beautiful and Sublime" (1764) ${ }^{31} \mathrm{He}$ might have taken their accomplishments as proving that at least in this respect women and men shared equal abilities. Instead, he suggests, with sarcasm and contempt, that they might as well have beards (II,230)-implying that learned women are not really women at all. In the Anthropology his reaction is still voiced in a similar tone: "As for the scholarly woman, she uses her books in the same way as her watch, for example, which she carries so that people will see that she has one, though it is usually not running or not set by the sun" (VII,307).

Further, Kant met women as a part of his social life. Many were well-educated and eager to discuss philosophy or politics with him, but he refused. If women persisted, Kant would no longer behave courteously towards them. ${ }^{32} \mathrm{He}$ preferred to discuss recipes with women, to the frustration of some of his female 
guests. On one occasion a guest reportedly exclaimed: "It really seems, dear professor, as if you regarded all of us as mere cooks.",33

One of Kant's regular guests and friends was Theodor Gottlieb von Hippel (1741-1796), mayor of Königsberg. Hippel is the author of the book Über die bürgerliche Verbesserung der Weiber ("On the Civil Improvement of Women" 1792) ${ }^{34}$ In this book Hippel argues in detail for more civil rights for women and tries to disprove most of the traditional legitimations for their subordination. It is uncertain whether Kant ever read the book, but he most probably knew of its existence and of the views held by his friend. ${ }^{35}$

As these examples show, Kant could have held different views on the status of women. Therefore, there is insufficient basis for excusing Kant's views on the matter as a mere product of the time.

b. A more fundamental problem with the third claim's reference to historical and biographical limitations is the following. Knowledge of biographical details and of general opinions of a particular period can often be of help for clarifying some philosopher's views by telling us where or how she or he got them. But it cannot affect the relative importance of these views themselves within the philosopher's work, i.e. it cannot reduce or enlarge the part they play within the larger whole. Thus, the fact that Kant had a pietist upbringing provides no argument for ignoring or downplaying the emphasis on "Gesinnung" in his practical philosophy. Similarly, the fact that either personal circumstances or general opinions in his time - or, for that matter, the work of Rousseauinformed his views on the sexes provides no argument for ignoring these views. So even if one would be willing to excuse Kant for holding them, this would not by itself entitle him or her to ignore these views. The issues of what caused or influenced Kant, and to what extent Kant is to be held responsible for his views, do not affect the relative importance of these views in terms of their impact on other parts of his moral and political philosophy. This importance has to be assessed by means of a systematic analysis of Kant's system of thought, and cannot be decided by historical or biographical data.

An example of what may happen when one too easily leaves aside Kant's views on the different characters of the sexes and their social, political and economic roles can be found in the book by Harry van der Linden, Kantian Ethics and Socialism (1988). Van der Linden mentions that Kant excludes women from citizenship. But except for one sentence (pointing to the fact that this exclusion involves a contradiction), he does not discuss the issue, only states that "historical limitations" play a role (198). Nonetheless, he phrases much of his discussion of Kant's political philosophy in the "we"-form. What I wish to indicate here, however, is how his lack of reflection on the sexism in Kant's political philosophy is mirrored in his own project.

Van der Linden describes the "over-all aim" of his book as "constructing a 
viable Kantian socialist ethics" (p.x). The largest section of his book consists of an extensive (and often illuminating) discussion of Kant's moral and political philosophy and his philosophy of history. Here he accentuates the social dimension in Kant's moral philosophy and tries to reformulate Kant's political philosophy along socialist lines, partly by mending inconsistencies in his thought, partly by further developing some of his views, for example with regard to the role of political institutions. Van der Linden holds that socialism overcomes significant social and economic inequalities taken more or less for granted by Kant, such as economic inequality and the division of labor between classes. His conclusion is that "socialist economic institutions instantiate the moral ideal, because they are to be defined as democratic institutions that aim at the satisfaction of the needs of all human beings" (164, emphasis added). But this conclusion seems far too strong. The author never discusses the social and economical inequalities between the sexes, nor the traditional division of labor between men and women that one finds in Kant's work. These aspects of the Kantian framework remain completely unchallenged.

As I have argued, taking over Kant's generic language without comment is problematic. Moreover, neither of the claims here discussed seems strong enough to justify ignoring Kant's sexism, and paying too little attention to the questions that emerge from Kant's sexism can lead one to unwittingly reproduce much of it. In what remains, I wish to outline a fourth approach, one that better accounts for the tension between Kant's generic language and his gender-specific remarks.

\section{OUTLINE OF A BETTER APPROACH}

In order to avoid distortions and ambiguities in representing Kant's thought, authors who discuss his moral or political philosophy need to make explicit the tension that exists between what Kant writes about "human beings" and what he says about "women." Although there may be specific cases where this tension is not relevant, one should be alert for instances in which Kant's views on the different characters of the sexes do play a role. And whenever there is such a case, it deserves at least some discussion. Thus, for example, the fact that Kant excludes women from citizenship deserves as much critical discussion as does his exclusion of male "passive citizens."

Making the tension explicit is going to affect the use of language in representing Kant's thought. There is, unfortunately, no simple linguistic solution to the problems that Kant's views on the sexes bring with them. For neither inclusive language nor naive reproduction of his use of "humanity," "human," etc. will suffice. Using inclusive language (e.g., "Kant thought that every human being should free herself or himself from tutelage") will not do because Kant did 
not think inclusively, and because it disguises Kant's exclusion of women. The same also goes for using Kant's own language (the ambiguous "Kant thought that every human being should free himself . . ."). A third alternative, namely replacing Kant's generic language by terms referring to men only ("Kant thought that every male should free himself . . . "), will not do either, because it would mean ignoring the fact that Kant spoke of the human species ("Gattung") instead of the male sex, even though he did so in a contradictory way.

In the absence of any simple, convenient linguistic device, any attempt to make explicit the tensions in Kant's thought will require some intervention in Kant's language, e.g. by commenting on his use of "human," "we," "citizen," and by avoiding expressions such as "our liberties" or "our political rights," "we as citizens," if women are excluded. "We" as the general subject of philosophical discussion can only be used in a gender-neutral sense, unless explicitly stated otherwise. ${ }^{37}$ There are countless other ways to draw attention, where appropriate, to Kant's limitation of his argument to men, such as interjected clarifying remarks, discussions, digressions, footnotes and annotations. The choice will mostly depend on one's creativity and style, on the context of argument and on the sort of text that is written.

Compared to commenting on and discussing Kant's thought, systematically appropriating Kant's political philosophy requires even more caution, if one does not wish to buy into its gendered presuppositions. For example, political theorists who wish to use a Kantian framework, and who wish to overcome Kant's polarization of the sexes, need to do more than introducing inclusive language and declaring that women can be treated as men. If one ignores Kant's ideas on the status of women, and simply treats his account of property, citizenship, etc. as applicable to women as well as to men, one still does not question Kant's polarization between the sexes on a fundamental level. Such an approach retains Kant's definition of the political domain (which is closely tied up with his views on the sexes) and leaves much of the division between masculine and feminine spheres in Kant's writings intact. One would only give women access to the masculine sphere, while remaining silent about the activities that Kant thought were to be performed by women, such as reproductive labor, care, and housekeeping. Thereby, one would still keep the latter outside of the range of political philosophy. Moreover, the ways of life, the standards and structures that developed in a male-dominated society, now dressed up in the clothes of equality, would remain unchallenged.

Truly overcoming the dichotomy would require a thorough re-evaluation not only of the concept of femininity, but also of that of masculinity in Kant's work. Only at that point will it be possible to rethink the meaning of "human." The results of this - comprehensive - enterprise will significantly shape the answer to 
the important, but difficult question of what implications the re-examination of Kant's views on the sexes would have for his moral theory of the Foundations of the Metaphysics of Morals and the Critique of Practical Reason. A prerequisite for all of this is an analysis — only sketched here - of the way Kant's views on the different "characters" and spheres of men and women are embodied in his work.

Washington University in St. Louis

\section{NOTES}

I am very grateful to Joel Anderson for his discerning comments on earlier versions of this essay.

Unless otherwise noted, all page references are to Kant's Gesammelte Schriften, edited under the auspices of the Königliche Preussische Akademie der Wissenschaften, Berlin: Walter de Gruyter, $1902-$.

Quotes are from the following translations:

Anthropology from a Pragmatic Point of View, Mary J. Gregor (The Hague: Martinus Nijhoff, 1974).

Critique of Practical Reason, Lewis White Beck (Indianapolis: Bobbs-Merrill, 1956).

Foundations of the Metaphysics of Morals; What is Enlightenment? and a Passage from the Metaphysics of Morals, Lewis White Beck (Chicago: University of Chicago Press, 1950).

Kant's Political Writings, ed. Hans Reiss, transl. H. B. Nisbet (Cambridge: Cambridge University Press, 1970).

The Metaphysical Elements of Justice, John Ladd (Indianapolis: Bobbs-Merrill, 1965). Incomplete translation of part I of the Metaphysics of Morals.

Abbreviations used:

Anthr. = Anthropology from a Pragmatic Point of View; Ed. = Lectures on Education; M.M. $=$ Metaphysics of Morals; Pr.R. $=$ Critique of Practical Reason $;$ Rel.$=$ Religion Within the Limits of Reason Alone; T\&P = On the Common Saying: "This May be True in Theory, but it Does not Apply in Practice."

1 Cf. Lorenne M. G. Clark, and Lynda Lange (eds.). The Sexism of Social and Political Theory: Women and Reproduction from Plato to Nietzsche, Toronto/Buffalo/London: Toronto University Press, 1979; Ellen Kennedy and Susan Mendus. Women in Western Political Philosophy: Kant to Nietzsche, Brighton: Wheatsheaf Books, 1987; Genevieve Lloyd. The Man of Reason: 'Male' and 'Female' in Western Philosophy, London: Methuen \& Co, 1984.

2 In 1986 the American Philosophical Association published "Guidelines for Non-Sexist Use of Language." Although these guidelines in many cases provide helpful suggestions, they unfortunately do not touch these questions. Proceedings and Addresses of the American Philosophical Association 59 (1986), 471-484.

3 I use the German word here, since the difference between "Mensch" (member of the human species) and "Mann" (member of the male sex) in the original texts tends to be wiped out in English translations.

4 Compare for a range of interpretations of Kant's views on the sexes: Heidemarie Bennent. Galanterie und Verachtung: Eine philosophiegeschichtliche Untersuchung zur Stellung der Frau in Gesellschaft und Kultur, Frankfurt/New York: Campus Verlag, 1985, 96-108; Silvia Boven- 


\section{PAULINE KLEINGELD}

schen. Die imaginierte Weiblichkeit: Exemplarische Untersuchungen zu kulturgeschichtlichen und literarischen Präsentationsformen des Weiblichen, Frankfurt/M: Suhrkamp Verlag, 1979, 224-244; Jean Grimshaw. Feminist Philosophers: Women's Perspectives on Philosophical Traditions, Brighton: Wheatsheaf Books, 1986, 42-49; Ursula Pia Jauch. Immanuel Kant zur Geschlechterdifferenz: Aufklärerische Vorurteilskritik and bürgerliche Geschlechtsvormundschaft, Wien: Passagen Verlag, 1988; Sarah Kofman. "The Economy of Respect: Kant and the Respect for Women" in: Social Research 49 (1982) 383-404; Susan Mendus. "Kant: An Honest but Narrow-Minded Bourgeois?" in: Ellen Kennedy \& Susan Mendus. Women in Western Political Philosophy 21-43; Susan Moller-Okin. "Women and the Making of the Sentimental Family" in: Philosophy and Public Affairs 11 (1981), 65-88, esp. 78-82; Howard Williams. Kant's Political Philosophy, Oxford: Basil Blackwell, 1983, 114-124.

5 On the notion of character in Kant, with special attention for his account of women's character, see Jean P. Rumsey. "The Development of Character in Kantian Moral Theory" in: Journal of the History of Philosophy XXVII (1989), 247-265.

6 Correspondingly, Kant's only mention of women in the Enlightenment essay occurs where he argues that many people, "including the entire fair sex," think that the step to "Mündigkeit" is very dangerous (VIII,35). Notwithstanding the criticism that is implicit in his remark that it is mainly the "guardians" who make people think so, Kant fails to develop a parallel case for men's guardianship over women. Therefore, there is no reason to regard the essay as an "Egalitätsentwurf' (Bennent, Galanterie und Verachtung 96, let alone to maintain that Kant, by mentioning the "fair sex," "directly asks for a political reform," albeit with "hidden clarity" (sic, "versteckte Deutlichkeit"), Jauch, Immanuel Kant zur Geschlechterdifferenz, 123.

7 Kant himself states that this "feminine principle" seems hard to unite with the notion of "character" "in the strict sense," character "in the strict sense" being a steadfast disposition to act according to moral principles (cf.VII, 285,292). In the early "Observations on the Feeling of the Beautiful and the Sublime" Kant literally says he hardly thinks that the female sex is capable of principles (II,232).

8 For an acute analysis of the contempt for women which is present throughout Kant's description of women in the Anthropology, see Bennent, Galanterie und Verachtung, 96-108.

9 This is stressed by Williams, Kant's Political Philosophy, 114ff.

10 Against Jauch, who overstates her case when she calls marriage an "Enklave der intersexuellen Egalität" (Immanuel Kant zur Geschlechterdifferenz, 164). Cf. "Die Frage des Eherechts wird zum endgültigen Ort der Einsicht in die Notwendigkeit der Überwindung der Geschlechterpolarisation", ibid., 161. Elsewhere she seems to contradict her own analysis, 1766 .

11 Mendus, "Kant: An Honest but Narrow-Minded Bourgeois?," 32.

12 This was reflected in the dictionaries of the time. In Johann Heinrich Zedler's Grosses Vollständiges Universallexikon we find under "woman": "Frau oder Weib ist eine verehlichte Person, so ihres Mannes Willen und Befehl unterworfen, die Haushaltung führet, und in selbiger ihrem Gesinde vorgesetzt ist . . " Bd.9, p. 1767 (Graz: Akademische Druck und Verlagsanstalt, 1961, reprint, Halle/Leipzig 1732-1754).

13 Cf. how Milton overrides his wife's wishes, in the example given by Kant: Anthr., VII, 308.

14 My translation, cf. Nisbet's translation, p. 78. ("Die dazu erforderliche Qualität ist, außer der natürlichen ( $\mathrm{da} \beta$ es kein Kind, kein Weib sei), die einzige: $\mathrm{da} \beta$ er sein eigener Herr sei.")

15 Bruno Bobrik. "Immanuel Kant's Ansichten über das weibliche Geschlecht" in: Altpreussische Monatschrift 14, (1877), 593-612. P.593: “ . . was gerade in unseren Tagen, in denen man . . . besonders bemüht ist die von Natur gesteckten Schranken weiblichen Erkennens und Wissens zu durchbrechen, von allgemeinerem Interesse zu sein versprach."

16 Karl Vorländer, Immanuel Kant. Der Mann und das Werk, Hamburg: Felix Meiner Verlag, 1977, (orig.1924), 160. Cf. his use of the word "we" [men] on p. 127. 
17 Roger Scruton, Kant (Oxford: Oxford University Press, 1982), p. 9.

18 Roger J. Sullivan. Immanuel Kant's Moral Theory (Cambridge etc.: Cambridge University Press, 1989), 376, n.26. Sullivan is so consistent with his own rule that in his main text he does not treat Kant's views on women at all. At the same time, however, he not only uses the "we," but sometimes also inclusive language when presenting Kant's moral philosophy.

19 I will refer almost exclusively to monographs on Kant's moral and political theory that appeared in the ' 80 s and ' 90 s.

20 Cf. William James Booth. Interpreting the World: Kant's Philosophy of History and Politics Toronto/Buffalo/London, 1986; Wolfgang Kersting. Wohlgeordnete Freiheit: Immanuel Kants Rechts- und Staatsphilosophie Berlin/New York: Walter de Gruyter, 1983. Harry van der Linden. Kantian Ethics and Socialism, Indianapolis/Cambridge: Hackett Publishing Company, 1988; Leslie Arthur Mulholland. Kant's System of Rights, New York: Columbia University Press, 1990; Patrick Riley. Kant's Political Philosophy, Totowa NJ: Rowman and Littlefield, 1983; Susan Meld Shell. The Rights of Reason: A Study of Kant's Philosophy and Politics, Toronto/Buffalo/ London: University of Toronto Press, 1980; Williams, Kant's Political Philosophy; Yirmiahu Yovel. Kant and the Philosophy of History, Princeton: Princeton University Press, 1980.

21 Williams, Kant's Political Philosophy, 183.

22 When Kant wrote, he still addressed himself to an almost completely male audience. Thus, in "Observations on the Feeling of the Beautiful and the Sublime," in his treatment of the relationship between the sexes, he used "we" to explicitly refer to the male sex (II,229).

23 Sullivan, Kant's Moral Theory, 262, cf. 204, 214, 216 and $254 \mathrm{ff}$.

Victor Seidler (Kant, Respect and Injustice: The Limits of Liberal Moral Theory, London/ Boston/Henley: Routledge \& Kegan Paul, 1986) poses a special case. He uses inclusive language (e.g. 12, 48), but also a questionable form of "we." Especially in the second half of his book, one finds it used referring to males. Cf. "It is the implicit rationalism that makes woman's experience problematic but which also renders invisible the difficulties men can have in emotional relationships. . . . In the moral culture Kant helps prepare men become fearful of showing signs of weakness and vulnerability, since we are convinced that, in the competitive world, this would quickly be used against us" (214). Compare "our masculinity" (141), "we as men" (151).

24 Bennent, Galanterie und Verachtung, 97. Also mentioned in Jauch, Immanuel Kant zur Geschlechterdifferenz, 18.

25 Sometimes men had to make explicit that indeed women were excluded even though a text was written in gender-neutral terms, as in the following example. When the Dutch constitution of 1848 and the franchise law of 1850 were drawn up, it was unimaginable that women would ever ask for the right to vote. No explicit prohibitory clause was included. In 1883, Aletta Jacobs, the later leader of the Dutch women's suffrage movement, became aware of this omission and of the fact that gender-neutral terms were used in the law texts. She was a medical doctor who paid enough taxes to qualify for voting rights, and appealed all the way to the High Court in order to get these rights. Her claim was dismissed, with the argument (among other, formal arguments) that she could not be considered to be in the full possession of her civil rights and rights to citizenship; that the terms "Netherlander" and "subject" had to be understood as referring to the man, "because were this not the case . . . it would undoubtedly have been stated clearly and unequivocally" (emphasis added), Weekblad van het regt 4917, 7.Aug.1883, p.1.

26 Cf. Otfried Höffe. Immanuel Kant, München: C. H. Beck, 1983, 208. Höffe uses the argument to defend Kant's political philosophy against its critics: one should put aside ("beiseitelegen," 209) its problematical elements, among which he mentions Kant's views on marriage and the superiority of the male sex, and concentrate on Kant's "main philosophical concern."

27 J. H. W. Stuckenberg. The Life of Immanuel Kant, Lanham/New York/London: University Press of America, 1986 (orig.1882), p. 184. 


\section{PAULINE KLEINGELD}

28 Van der Linden, Kantian Ethics and Socialism, 198.

29 Sullivan, Immanuel Kant's Moral Theory, 376, n.26.

30 Stuckenberg, Life of Immanuel Kant, 184. Also quoted by Williams, Kant's Political Philosophy, 121.

31 Kant polemicized against Mme. du Chatelet in his early essay "Gedanken von der wahren Schätzung der lebendigen Kräfte" (1747), AA I, 45, 55, inter alia.

32 Cf. Wolfgang Ritzel. Immanuel Kant: eine Biographie (Berlin/New York: Walter de Gruyter, 1985), 125; Stuckenberg, The Life of Immanuel Kant, 186.

33 Stuckenberg, The Life of Immanuel Kant, 186. More similar anecdotes are to be found here.

34 (Berlin: Vossische Buchhandlung). Cf. Ruth P. Dawson, "The Feminist Manifesto of Theodor Gottlieb von Hippel (1741-96)" in: Amsterdamer Beiträge zur neueren Germanistik, Bd. 10 (1980), 13-32.

35 The book was published anonymously, but its author soon became publicly known. Nonetheless, in $1796 \mathrm{G}$. A. Flemming asserted that Kant was the author of this and three other books by Hippel, which Kant denied. See his declaration, AA XII,386f. See also: Arthur Warda, "Kants Erklärung wegen der v. Hippelschen Autorschaft" in: Altpreussische Monatsschrift XXXXI (1904), 61-93, and Jauch, Immanuel Kant zur Geschlechterdifferenz, 203ff. Jauch's renewed suggestion that Kant was co-author of the book is not convincing.

36 Kersting, Wohlgeordnete Freiheit, does not discuss the juridical status of women in Kant's Metaphysics of Morals, although his comprehensive study is intended to be a "umfassende philosophische Rehabilitierung der Rechtsphilosophie Kants" as found in the Metaphysics of Morals, and an analysis of its 'Leistungsfähigkeit' (VII). His discussion of "passive citizenship" focuses on problems of class and property-ownership (248-257).

37 This obviously does not only hold for the issue of gender, but also for that of race, sexual orientation, and social status. 